\title{
Childhood Conception on Child Periodicals of Second Constitutional Period*
}

\begin{abstract}
Ali GURBETOĞLU**
ABSTRACT. In this article, childhood conception of Second Constitutional Period is studied as per the child periodicals of the period. Educational approach of the period is tended toward the training of socio-economic problems. Child periodicals of the period constitute evidence for that childhood conception is formed by the same thought and view. The period has its own child and childhood demand which is unique for its own conditions. The objective of the study is to reflect the aimed childhood over child periodicals. Under the content of the study, nearly 500 editions of 22 child periodicals with approximately 5000 pages which were published between 1908 and 1918 were researched. The mentioned periodicals were investigated and evaluated under the titles of childhood conception, child and education, child and intelligence, child and environment, children rights and duties, culture of obeying and respect, child and game and children games.
\end{abstract}

Key Words: Childhood, child, childhood of Constitutional Period, child education, history of childhood, child and game, children rights, child periodicals

\footnotetext{
* This article is a part of a Ph.D. study which was completed in 2007 in Ankara University. The title of the doctoral thesis is "A Study on Child Periodicals Printed in the Second Constitutional Period Era (1908-1918) from Educational Aspect".

${ }^{* *}$ Ph.D., Ankara University, Faculty of Educational Sciences. agurbetoglu @ yahoo.com
} 


\section{SUMMARY}

The Second Constitutional Period is the years of seeking solution by intellectuals in order to save the Ottoman Empire from collapse. These years have a distinct importance on Turkish education history because they include a very important experience for the educational applications, principles and complements of the Republic which would be founded later. This period, which is also characterized as a kind of laboratory for the period of Republic, represents a significant bounce on media life, especially on child media. Relatively comprehensive information and findings on the child fact and childhood concept of the period can be found on child periodicals. For that reason it is important to bring up the childhood concept of Second Constitutional Period as per the aspect that it was reflected to the child periodicals.

The aimed child type is desired to be furnished with the idealist emotions of Second Constitutional Period; to pass adulthood easily; and to have versatile skills. Within this aim, giving a national soul to the children has been the first aim. It was thought that this soul could be given by implanting the love of country, nation and state. In accordance with the principle of "according to child", giving these emotions through tales, stories and poems is preferred for permanence and easiness. Within this aim, child periodicals have also tried to make contribution to educational institutions and official state policies on their own area.

The main duty of the child is to obey and to memorize the school lessons. The child is responsible to both family members and society in consideration of the self-sacrifice of his/her family. So, education has been seen as a process for giving a consciousness to the child in order to comprehend and fulfill these duties faithfully.

For child, game is a means for comprehending and understanding the events and facts and recognizing the environment, world and objects. Game is the most important means for physical, mental and intellectual development of the child. With these features, game has been a good educational tool and thus indispensable subject of education and educators.

It is thought that there were negative approaches and attitudes toward child and game and the basic reason was incognizance of childhood concept and children psychology. The adults are accused of shading the childhood life for their own peace and comfort.

Old-new comparisons have been often made on periodicals about childhood. A connection is made between historical development of 
humanity and historical development of childhood. As a result, during the development of humankind, childhood will develop by the way.

Another duty undertaken by the child periodicals of Second Constitutional Period is to focus on the negative meanings carried by absolutism which is the prior period of Constitutional Period and to make the children adopt, defense and reverence the constitutional system by expressing the success and excellence of constitutional system on removing these negative effects of absolutism. The future generation is desired to be train through this awareness of bad example of the past. It is the most important aim of old-new comparisons reflected to child periodicals. Repressive system of the period before constitutional period is criticized for destroying the individual entrepreneur soul and working determination which were rarely seen on people. The main aim has been to train an enterprising, informed, hardworking and productive generation with a determination and will overcoming the current problems easily by learning from the success of the ancestors with the consciousness of national identity on an independent environment. Because only such a generation can repair the broken national honor; remove the experienced drams and difficulties; help the society to release from material and moral crisis; and especially make up for lost ground. It is clearly seen that, all institutions and organizations beginning from the family are in an effort to make contribution for training such a generation. 


\title{
II. Meşrutiyet Dönemi Çocuk Dergilerinde Çocukluk Anlayıșı*
}

\begin{abstract}
Ali GURBETOĞLU**
ÖZ. Bu makalede II. Meşrutiyet dönemi çocukluk anlayışı dönemin çocuk dergileri üzerinden incelenmiştir. Dönemin eğitim anlayışı yaşanan sosyo-ekonomik sorunların çözümünü sağlayacak neslin yetiştirilmesine dönüktür. Çocukluk anlayışı da aynı düşünce ve bakışla şekillendirildiğine dönemin çocuk dergileri tanıklık etmektedir. Dönemin kendi şartlarına has bir çocuk ve çocukluk talebi vardır. $\mathrm{Bu}$ çalışma hedeflenen çocukluğun ne olduğu yansitılmaya çalışılmıştır. Çalışma kapsamında 1908 - 1918 yılları arası yayımlanmış 22 adet çocuk dergisinin yaklaşık 5000 sayfa tutarında 500 e yakın sayısı incelenmiştir. Söz konusu dergiler çocukluk anlayışı, çocuk ve eğitim, çocuk ve zeka, çocuk ve çevre, çocuk hakları ve görevleri, itaat kültürü ve saygı, çocuk ve oyun, çocuk oyunları gibi başlıklar altında incelenerek değerlendirilmiştir.
\end{abstract}

Anahtar Sözcükler: Çocukluk, çocuk, meşrutiyet çocukluğu, çocuk eğitimi, çocukluk tarihi, çocuk ve oyun, çocuk hakları, çocuk dergileri

* Bu makale 2007 yılında Ankara Üniversitesi Eğitim Bilimleri Fakültesi’nde sunulmuş olan "II. Meşrutiyet Döneminde Yayımlanan Çocuk Dergilerinin Eğitim Açısından İncelenmesi (1908-1918)" adlı doktora tezinin bir kısmından özetlenerek alınmıștır.

** Dr. Ankara Üniversitesi Eğitim Bilimleri Fakültesi. agurbetoglu@yahoo.com 


\section{GİRIS}

II. Meşrutiyet dönemi Osmanlıyı yıkılmaktan kurtarmak için aydınların çare arayış yıllarıdır. Bu yıllar, daha sonra kurulan Cumhuriyetin kadroları, ilkeleri ve eğitim uygulamaları için çok önemli bir tecrübeyi barındırması nedeniyle Türk eğitim tarihinde ayrı bir öneme sahiptir. Cumhuriyet dönemi için bir tür laboratuvar olarak da nitelendirilen (Akyüz,2006: 243) bu dönem, basın hayatı ve özellikle çocuk yazını alanında önemli bir sıçramayı da ifade etmektedir. Dönemin çocuk dergilerinde çocuk olgusu ve çocukluk anlayış1 konusunda oldukça kapsamlı bilgi ve bulgular mevcuttur. O nedenle II. Meşrutiyet dönemi çocukluk anlayışının, dönemin çocuk dergilerine yansıdığı yönüyle ortaya konması önemlidir.

23 Temmuz 1908 inkılâbıyla sağlanan aşırı özgürlükçü ortamda devrin fikir hayatında ortaya çıkan çeşitlilik, dönemin basın hayatına da canlılık getirmiştir. Bu yönüyle II. Meşrutiyet dönemi Osmanlı basını için adeta yeniden doğuş dönemi olarak nitelendirilebilir. Oluşan özgür ortamda ülke ve toplumun sorunları ayrıntılı olarak tartışılmış, tartışılan fikirler, ortaya çıkan çok sayıdaki süreli yayınlar yoluyla geniş halk kitlelerine ulaştııılmıştır. $\mathrm{Bu}$ dönemde diğer basın organları yanında çocuk dergiciliğinin de önem kazandığı ve çok sayıda çocuk dergisinin yayımlandığ1 görülmektedir. ${ }^{1}$ Türk toplumunun geleceğini büyük ölçüde etkilediği daha sonra görülecek olan basın hayatındaki bu gelişmeler, Türkiye'de çocukluk tarihi açısından ayrı bir öneme sahiptir.

Mevcut sıkıntıların eğitim sisteminden kaynaklandığının düşünülmesi bu kuruma olan güveni sarsmakla birlikte, Balkanlarda yaşanan hezimetlerin hazırlayıcısı, düşman topluluklarının eğitim sistemi ve öğretmenlerinin kendi hesaplarına başarıları olarak değerlendirilmiştir. Osmanlının yenilgisinin de önemli ölçüde öğretmenlerinden ve eğitim sisteminden kaynaklandığ 1 düşünülmekteydi. (Akyüz, 1978: 139). O nedenle kurtuluşun çaresi paradoksal bir biçimde yine eğitim sisteminin ve okul kurumunun 1slahında görülmüştür. Bu kurumların, çağın gereğine göre ıslah edilmesi ve buralarda günün ihtiyacına göre adam yetiştirmesi önemli bir eğitimsel hedef olmuştur. Mevcut koşulların da yönlendirmesiyle eğitim kurumlarının tamamen pragmatik amaçlara yönelmiş olduğu görülmektedir. Ülkenin var olma mücadelesiyle karşı karşıya bulunması eğitimi de etkilemiştir. O nedenle eğitim sisteminden, milli birlik ve bütünlügü sağlamaya yönelik bilinçli bireyler yetiştirmesi, vatanın savunulması ve yüceltilmesine yönelik duyarlılıklar kazandırması beklenmiştir. Devrin eğitim kurumları bu donanıma sahip neslin yetiştirilmesi gibi çok önemli bir görevi üslenmiştir.

\footnotetext{
${ }^{1}$ Araştırma kapsamında tespit edilip değerlendirmeye alınan dergi sayısı yirmi ikidir.
} 
$\mathrm{Bu}$ dönemde kadın, aile, çocuk gibi o zamana kadar pek önemsenmemiş toplumsal unsurları, edebi eserlerin ve çeşitli makalelerin konusu olmuş, bu konuların işlendiği yayınlar çoğalmaya başlamıştır. Bu cümleden olarak pek çok kadın, aile ve çocuk gazete ve dergisi yayımlanmıştır. Bu yayınlarda temel amaç asırlarca ihmale uğramış bu toplumsal kesimlerin eğitilmesi olmakla birlikte ülke savunmasında bu kesimlerin de aktif görev üslenmelerini sağlamaktır. Çocukların ilk eğiticisi konumundaki kadınların eğitimi bu amaçla önemli görülmüş, kadınlara yönelik öğretim kurumlarının geliştirilmesine ağırlık verilmiştir (Akyüz, 2001: 58) Çocuklara vatan, millet, devlet sevgisi aşılanarak milli bir ruh kazandırılması ilk hedef olmuştur. Çocuk dergileri de aynı amaca yönelik olarak eğitim kurumlarına ve resmi devlet politikalarına kendi kulvarlarından katkı sunmaya çalışmışlardır.

\section{Çocukluk Anlayışı}

Toplumlar kendi ideallerini çocuklar yoluyla geleceğe taşıdıkları için çocukların eğitimine her zaman önem vermişlerdir. Özellikle bunalım zamanlarında sorunlara çözüm arayışında çocuklar ilk sırada düşünülmektedir. Çünkü çocuk mensubu bulunduğu ailenin ve toplumun bir üyesi olarak sorumluluklar üstlenecektir. Toplumun geleceği ona bağlandığ 1 için her devrin çocukluk anlayışı büyük ölçüde toplumcu bir anlayış ve bakışla şekillenir.

II. Meşrutiyet dönemindeki çocukluk anlayışının aynı düşünce ve bakışla şekillendirilmek istendiğine dönemin çocuk dergileri tanıklık etmektedir. Dönemin şartlarına özgü bir çocuk ve çocukluk talebi vardır. $\mathrm{Bu}$ talep büyük ölçüde yaşanan sıkıntıların özeleştirisiyle, geçmişte yapılan hatalar 1şığında şekillendirilmiştir. Buna göre hataların başında ailelerin çocuk terbiyesi konusundaki duyarsızlığı ve bilgisizliği gelmektedir. Eğitim sisteminin çocuğa milli bir kimlik ve milli bir ruh veremeyişi de sorunun bir diğer önemli nedeni olarak öne çıkmaktadır. Meşrutiyet öncesinin baskıcı sistemi insanlarda zayıf olan çalışma azmi ve bireysel girişimcilik ruhunu tamamen yok etmekle eleştirilmektedir. Özgür bir ortamda, milli kimliğinin bilincinde, atalarının geçmiş başarılardan ibret alan, mevcut sıkıntıları kolaylıkla aşabilecek azim ve iradeye sahip, girişimci, bilgili, çalışkan ve üretken bir nesil yetiştirilmesi temel hedef olmuştur. Ancak böyle bir nesil kırılan milli onuru tamir edebilecek, yaşanan dramların ve felaketlerin öcünü alabilecek, toplumu içinde bulunduğu maddi ve manevi krizlerden kurtarabilecek ve nihayet hepsinden de önemlisi kaybedilen toprakları geri kazanabilecektir.

$\mathrm{Bu}$ süreçte çocuk dergileri de hedeflenen neslin yetiştirilmesinde diğer eğitici kişi ve kurumlar gibi görev üstlenmişlerdir. Bu bir entelektüel duyarlık olduğu kadar vatanseverliğin de gereğidir, hatta çocuk dergileri genellikle, kendi varlık sebebini bu anlayışa dayandırmışlardır. Bu nedenle 
sırf çocuk eğitimine ilgi göstermekle yetinmemişler, çocuğun eğitimiyle yükümlü kurum ve eğiticilerin eğitilmesi, eğitim alanındaki çağdaş gelişmelerden bu kişi ve kurumların gereğince haberdar olup yararlanması için de çaba sarf etmişlerdir.

Çocuğun ilk eğitim yuvası aile kurumu olduğundan çocuk dergilerinde aile bireylerinin eğitimine ilişkin bilgilendirici ve yönlendirici içeriklere yer verilmiştir. Çocuk Dünyası'nda çocuk eğitimi konusunda ailelerin bilgisiz ve duyarsız olduklarından söz edilmiş, bunun sadece eğitimsiz ailelerde değil genelde her Türk ailesinde yaygın olduğu belirtilerek bu tutum eleştirilmiştir ("Çocuk Dünyasının Düşüncesi,"1913:1). Devrin bilinç kavramı sorgulanmıştır ki, bu anlayışa göre bilinçli bireylerler yüksek edebiyat mecmuası okuyan, fen ve siyaset konularıyla yakından ilgilenenlerdir. Oysa gerçek bilinçli birey çocuğunun eğitimiyle ilgilenip ona aydınlık bir gelecek hazırlamaya çalışır. Böylece çocuğunu gelecekte başkalarına muhtaç olmaktan kurtardığ 1 gibi bu duyarlılığıyla ülkesine ve milletine de hizmet etmiş olur.

Bilinç konusunda aydın sorumluluğuna özellikle dikkat çekilmiş, batıda çocuk edebiyatına verilen önemden söz edilerek, batılı örneklerinde olduğu gibi bizde de çocuk edebiyatına önem verilmesi istenmiştir. Batılı düşünürlerin çocuk hayatına ve çocuk edebiyatına verdikleri önemi göstermesi açısından Tolstoy örnek gösterilmektedir. Buna göre, "Tolstoy hayatının bir kısmını çocuklar için basit fakat son derece nefis masallar yazarak geçirmis ve hatta kendi köyünde açtı̆̆ mektepte ömrünün sonuna kadar köylü çocukların terbiyesiyle meşgul olmuştur." ("Çocuk Dünyasının Düşüncesi,” 1913:1). Tolstoy ünlü bir yazar olarak çocuk edebiyatına ve çocukluk konusuna eğilmiştir. Bu bir aydın duyarlığg olarak övülmektedir. Oysa Osmanlı aydını çocuk konusunu küçümsemiştir. Bu alandaki ihmalin temel nedeninin bu küçümseme tavrı olduğu düşünülmektedir. Çocuk edebiyatına yönelik ürünler önemsiz görüldüğünden bu alan boş bırakılmıştır. $\mathrm{Bu}$ boşluğun doldurulması için Osmanlı yazar ve aydınına, çocuk edebiyatı ürünlerine ağırlık vermeleri çağrısı yapılmıştır.

Çocuk edebiyatı ürünlerin ne tür içerik ve temaya sahip olması gerektiğine ilişkin belirlemelerde Batı vurgusu hemen dikkat çeker. Örneğin çocuklarda okuma sevgisi meydana getirmede, onları zihni faaliyete alıştırma ve fikirlerini terbiye etmede Batılıların efsanelerden, fabllardan, masallardan yararlandıkları belirtilmiştir. Batıda çocuk edebiyatı eserlerinin bunlarla dolu olduğu, bunlar yardımıyla, çocuğun seviyesine uygun bu tür içeriklerle çocuklara okuma sevgisi ve zevki kazandırıldığı tezi işlenmiştir. Okuma zevkinin çocuklara kazandırılması da çocuk edebiyatının gelișmesiyle sağlanabilir. Aksi durumda çocukların eline verilecek eserler üslup ve içerik bakımından onların seviyesine uygun olmayacağından olumsuz sonuçlar verecektir. "Okumayı henüz yeni söken bir küçügün gözü 
önüne çetin ve sıkıcı yazılar yığıp da mütalaa ile arasında, daha başlangıçta fena bir imtizaçsızlık, soğukluk tevlit etmektense, kendisine pek de yabancı olmayan hikayelerle onda okumaya karşı sevgi ve istek uyandırmak elbette daha doğru bir hareket olur" ("Çocuk Dünyasının Düşüncesi," 1913:1). O nedenle bu tür eserlerin ihmal edilmesi yanlış olmuştur. İhmal nedeniyle oluşan boşluğun doldurulması gereklidir. Bunun şimdilik kaydıyla çözümünün tercümelere ağırlık vermekle mümkün olabileceği belirtilmiştir. Birçok dergi bu yaklaşımı benimsemiş, Fransız, İngiliz, Alman ve Rus çocuk edebiyatına ait eserlerden pek çok tercümeler yayımlamıştır. Ayrıca milli çocuk edebiyatını geliştirmek adına "milli hikayeler" başlığı altında hikayelere yer verilmiştir. Yine çocuk şiirleri yayımlama konusunda dergilerde bir gayret görülmektedir. Ancak burada hemen belirtilmelidir ki, siyasal problemler çocuk edebiyatının sağlıklı gelişmesini engelleyen en önemli faktör olmuştur. Çocuk edebiyatı adına ortaya konulan edebi içerikler Balkan savaşlarında yaşanan facia ve hezimetlerin oluşturduğu nefret ve düşmanlık duygularının etkisinde ve gölgesinde gelişme göstermiştir.

\section{Çocukluğun Anlamı ve Önemi}

Dönemin çocuk dergilerinde hedeflenen çocuk tipi, II. Meşrutiyet döneminin idealist duygularıyla donatılmış, en kısa yoldan yetişkinliğe geçmesi beklenen ve çok yönlü becerilere sahip olan çocuktur. Okul öncesine yönelik olduğu izlenimini veren Çocuk Dostu'nda öne çıkarılan ideal çocuk çalışkan, iyi yürekli, doğru sözlü, annesini üzmeyen, onun sözünden çıkmayan bir Türk çocuğudur. ("Küçük Turgut'un El İşleri," 1914:2). Arkadaş dergisi de benzeri özellikleri öne çıkararak fedakâr, hemcinsinin hukukuna riayet eden ve çalışkan çocuk tipine vurgu yapar ("Hayat1 Öğrenelim," 1910:71).

Devrin koşullarının da etkisiyle çocukluk en kısa süre içerisinde geçilmesi, aşılması gereken bir devre olarak düşünülmüştür. Bunun sebebi, mevcut siyasal-sosyal koşulların çocukluğu olabildiğince kısa sürede aşılması gereken bir devre haline dönüştürmesidir. Çocuk Duygusu'nda yer alan bir makalede dönemin eğitim sistemi ve öğretim yöntemleri eleştirilmektedir (Ahmet Hamdi,1913:2). Eleştirilerin yoğunlaştığ noktalardan birisi de çocukluğun uzun sürmesidir. Bu konuda "sizi yirmi yaşına kadar çocuk birakan miskin ve murdar usul-i terbiyeyi kaldırmaya çalışacağız" denilerek, çocukluğun uzamasının hata olduğu, bunun eğitim sisteminin bozukluğu ve öğretim yöntemlerinin yanlışlı̆̆ından kaynaklandığı ileri sürülmüştür. $\mathrm{Bu}$ anlayışa göre çocukluk kıssa sürede aşılması gereken, yetişkinlik hayatına hazırlık devresidir. Eğitim bu devreyi olabildiğince kısaltan ve çocukluktan yetişkinliğe geçişi kolaylaştıran bir araç konumundadir. 
Çocuk dergileri için "Çocuk nedir?” sorusu önemli görülmüştür. Bu soru çocuk dergilerinin büyük çoğunluğunda gündeme getirilmiş fakat ayrıntılı tartışılmamıştır. "Sultan Orhan Oniki Yaşındayken" adlı Özdemir imzalı yazıda (Özdemir,1914a:65) çocuk kavramının Osmanlı toplumunda önemsenmeyen, bilinmeyen bir kavram olduğu belirtilmektedir:

"Bizim şarkımızın son yıkıntı senelerinin en fena işlerinden biri de çocukluğa hiç ehemmiyet verilmemesi ve çocuğa, henüz insan hukukuna nail olmamış eksik bir şey gözüyle bakmamızdır. Çocuk arzuları; 'adam! ...çocuktur' gibi hiç manasız bir lafla ihmal olunurdu. Çocuk ruhu güya henüz bir ruh değilmiş gibi muamele görürdü. Her millette kullanıldığından daha ziyade bizde 'Çocukluk' kelimesi münasebetsiz işleri anlatırdı. Bu derece ihmal edilen çocukluk iyi bir terbiye göremezdi. Zaten henüz bir terbiye usulü de yoktu" (Özdemir,1914a:65).

Özdemir'e göre büyükler tarafından önemsenmeyen çocukluğun ihmal edilmişliğinin faturası topluma çıkmaktadır. Çocuk geçmişte eğitimin bir öznesi olamadığı gibi nesnesi olarak bile değer görmemiştir. O çocuğun ihmal edilmişliğinden söz ederken onu eğitimin öznesi yapmak gibi bir düşünce de sergilemez, zira ona göre çocuk "Müstakbel Millet" demektir. Çocuklar yaşama kavgasının yarınki askerleridir. Dolayısıyla çocuk kendisi için var olmaktan çok içinde yaşadığı toplumun adına vardır ve o toplumun geleceğini kurmak ve gerektiğinde de kurtarmakla görevlidir. Türk milletinin geçmişteki başarılarında çocuk yaştaki yiğitlerin çok önemli katkıları olmuştur. Özdemir'e göre "O vakitler 15 yaşında bir çocuk, zamanımızın 25 yaşındakileri kadar aile ve millet hayatına alakadar bulunmakta imişler. 15 yaşındaki gazilerin ve şehitlerin sayısı insanın gözünü kamaştırır. Yine bu yaşta ailesine bakanlar, ticaret edenler, işçilik yapanlar sayısızdır" (Özdemir,1914a:66). Bu ifadede Özdemir'in şahsında dönemin çocuğa bakışı yansımaktadır. Diğer çocuk dergileri de benzer anlayışa sahiptir. "Musavver Şebab"da "Terbiye, Tahsil-i Etfal" (İsmail Faik, 1910:5) adlı yazıda "Çocuk nedir?" sorusuna cevap aranırken, eski dönemlerde ve özellikle istibdatta herkesin büyüklerle uğraştığından ve "gonca-i hayat" olarak tanımladığ 1 çocuklara hiç önem verilmediğinden şikayet edilmiş, Meşrutiyetle beraber durumun değiştiği belirtilmiştir. Burada geçmişe yönelik eleştiriler, çocuğun toplum adına ve toplumun geleceği için yeterli düzeyde eğitilmediği noktasında toplanmaktadır. Yoksa çocukluk ve çocuk kavramına yeni bir açılım, yeni bir bakış getirilmemektedir. Çocukluk gelecekte üstlenilecek görev ve toplumsal rollerle açıklanmaktadır. Buna göre "Vatanı muhafaza edecek çocuklar, gençler, memleketi besleyecek yine gençler ve çocuklardır. O halde çocuk nedir? Çocuklar hayat-ı saiyane (hayat habercisi) çiçeğidir. Çiçekler nasıl güneşe muhtaç ise gonca-i hayat olan çocuklar da öylece hayat güneşi olan terbiyeye müftekirdirler (muhtaç). Hükemâdan bir zat indinde ise; 'Çocuk, sonradan insan olacak bir 
melektir" (İsmail Faik, 1910:5). Görüldüğü üzere çocuk, toplumun geleceğine ait görevler üstlendiği konumdan itibaren insan kabul edilmektedir. Burada önemsenen çocuğun yaşı ve gelişimi değil, üstleneceği toplumsal role hazır olmasıdır. Eğitim de çocuğun, bu görevi üstlenebilecek yetkinliği en kestirim yoldan elde etmesinde araç olabildiği ölçüde önemlidir. "Yaşamak Üzerine" adlı bir yazıda çocuklara toplumun geleceği açısından ne kadar önemli oldukları şöyle anlatılmıştır:

"Bugün bir Osmanlı çocuğusun, yarın bir insan, bir Osmanlı vatanperveri olacaksın. Bugün iktisab-1 marifetle (ilim öğrenerek) kesb-i kemale(olgunluk kazanma) memur bir goncasın. Yarın hayatta bir mevki tutarak milleti, devleti ilâya(yükseltme) mükellef metin bir fedakar olacaksın. Bugün himmete muhtaç bir çocuksun. Ebeveynin, ailen, devletin, milletin seni talim ve terbiye ettirerek büyütüyor. Vatan seni yaşatıyor. Yarın kemalatı nefsinde cem etmiş ahlak sahibi bir insan olacaksın. Ebeveynine, ailene, milletine muavenetkâr (yardımcı) olarak, onları itilâlara (yükseklikler) doğru koşturup, vatanı sen yaşatacaksın” (M.F.Ş, 1913:2).

$\mathrm{Bu}$ açıklamalardan da anlaşıldığı üzere çocukluk tanım ve anlayışları açısından dergiler arasında ciddi farklılıklar bulunmamaktadır.

Dergilerde çocukluk konusunda eski-yeni karşıllaştırmalarına sıklıkla rastlanır. Bu konuda insanlığın tarihi tekâmülü ile çocukluğun tekâmülü arasında bir ilişki kurulmaktadır. İnsanlık tekâmül ettikçe çocukluk da tekâmül etmekte ve gelişmektedir. Çocuk Bahçesinde isimsiz olarak yayınlanan "Şimdiki Çocuklar" adlı yazıda o dönemdeki çocukluğun imkanlarının eski çocukla karşılaştırıldığında, çocukluğun iyiye doğru gittiğinin görülebileceği belirtilmiştir ("Şimdiki Çocuklar," 1914:1). Dönemin çocuk dergilerinin eski-yeni tartışması açmadaki diğer bir amac1, mutlakıyetin çocuklar için taşıdığı olumsuz anlamlarına vurgu yapmak ve meşruti sistemin bu olumsuzlukları gidermedeki başarılarını çocuklara kavratarak onları meşruti sistemin benimseyicisi ve savunucusu yapmaktır. Çocuk dergilerine yansıyan bu tür eski-yeni karşıllaştırmalarının en önemli amaci budur.

\section{Çocuk ve Eğitim}

$\mathrm{Bu}$ dönemde eğitimin temel amac1, çocuğu toplum için üstleneceği rollere hazırlamak olduğu için ona milli bir ruh kazandırılması eğitimin ilk hedefidir. Bu ruhun kazandirılması vatan, millet, devlet sevgisinin aşılanmasıyla mümkündür. Bu duyguların, kolay ve kalıcı bir öğrenmenin sağlanmasına yardımcı olması açısından masallar, şiirler, hikayeler yoluyla verilmesi düşünülmüştür. Kazandırılmak istenen duyarlılık için araç olabilecek türden şiir, masal, hikaye vb. edebi içeriklere ağırlık verilmiştir. 
Geleneksel eğitim, çocuğu, önceden belirlenen standartlara ulaştırılmayı biricik amaç edindiği gerekçesiyle eleştirilmektedir. Bu bir anlamda çocuğun kendi ilgi ve becerilerini bir tarafa burakarak ona göreceli bir ideal mükemmellik vermek demekti. Çağdaş eğitim anlayışları çocuğu eğitimin bir nesnesi olmaktan kurtarıp onu eğitimin öznesi haline getirmenin gereğine vurgu yapmaktadır. Bu yaklaşımı Rıza Tevfik, "Zamanımızın medeniyeti emr-i terbiyede (eğitim işinde) tabiat-ı tufûliyete karşı (çocukluk tabiatı) müstebidâne (baskıcı) davranmak hamakatinden (ahmakllk) kurtulmuş ve bilakis kendinden bîhaber olan bir nevzadı (genç) yavaş yavaş insan eden feyz-i garîzînin (fitrî gelişim) kuvayı nâmiyesini (artan güçler) kavânin-i vesâirini (diğer kurallar) keşfedip anlamak sevdasına düşmüştür. Tabiata karşı koymak değil onun iktizasınca hareket ederek çocukluğu terbiye eylemek yolunu bulmuşlardır ki, bu keşfin ne kadar büyük olduğunu muhtasaran tarif edemem" şeklinde dile getirmektedir (Rıza Tevfik, 1914:3). O, Batıda çocukluk anlayışının önemli bir ilerleme kaydettiğini düşünmektedir. Çocuk ailenin ilgi odağına girmiş, böylece eğitimin öznesi olma yolundaki en önemli engel olan ailenin çocuğa bakış1 olumlu yönde değişmiştir. Bunun çağdaş pedagojik gelişmeler sayesinde elde edilen bir kazanım olduğunu, çocuğa karşı tutum ve davranışların temelinde ilginin (alaka) bulunduğunu söyleyen Rıza Tevfik, "Bugün insaniyete, hele çocuklara her zamankinden ziyade alakadarız. Onları yakından tanımak ve mizaçlarına, tabiatlarına riayet etmek sevdasına düşü̈şüz. Onlar hakkında bu muhabbeti, samîm vicdanımızda duyuyoruz. Demek ki, bizim çocuklarımıza muhabbetimiz, ecdadımızın evladına muhabbetinden hem biraz ziyadedir hem de biraz daha başkadır" ş̧eklinde değişen çocukluk anlayışını çocuğa ilginin artmasına bağlamaktadır (Rıza Tevfik, 1913:3). Burada ailenin çocuğa karşı ilgisi açısından eski ve yeni çocukluk karşılaştırması yapılmıştır ki, yeni çocukluğun eskisine göre daha iyi bir konumda olduğu ve her geçen gün daha iyiye gittiği belirtilmiştir.

Anne babaların çocuk üzerindeki etkisi, çocuğa yönelik ilginin artmasıyla daha da güçlü hale gelmektedir. Çocuklar bu ilgiyi elde etmekle, geçmişteki çocukluktan ve çocuklardan çok daha şanslı bir hale gelmişlerdir. Dolayısıyla çocuk, kendi halinde yetişmeye bırakılacak bir nesne olmayıp her ilgisi ve her merakı eğitim açısından değerlendirilecek bir varlık konumunda değerlendirilmiştir. Bu durum Meşrutiyet aydınının çağının pedagojik gelişmelerini iyi takip ettiğini göstermektedir.

Çocuktaki bilme, anlama ve öğrenme merakının eğitici için çok önemli avantajlar sunduğunu düşünen Nezihi Behzat "Ihtiyac-ı Maarif" adlı makalede bu konuyu irdelemiştir. Ona göre öğrenme ihtiyacı doğuştan gelen özelliklerdendir. Öğrenme arzusu da çocuğun gelişim evrelerine göre farklılık göstermektedir. Çocuktaki bu gelişim evrelerinin iyi bilinmesi ve eğitim açısından değerlendirilmesi gereklidir (Nezihi Behzat, 1910:2). O 
ayrıca ilgi, öğrenme ve eğitim arasında yakın bir ilişkinin varlığından söz etmektedir. Ona göre çocuktaki öğrenme merakının iyi yönlendirilmesi onun düşünme, kavrama ve anlamasına yardımcı olur. O nedenle çocuğun her yaş ve seviyedeki ilgisi, eğitim açısından çok iyi değerlendirilmelidir.

Benzer şekilde "Hamdolsun Çocuklarımız Düşünüyor" başlıklı yazıda Özdemir adlı bir öğretmen çocuklarda ilgi konusuna eğilmiştir. Ona göre eski anlaysşta çocuğun herhangi bir konuda fikir yürütmesine izin verilmemesi nedeniyle çocuklar dünyadan habersiz yetişmekteydi. Hiçbir şeye karışmamak, olay ve olguları sorgulamamak üzere yetiştirilen çocuk, büyüyünce sorgulama ve sorumluluk alma duygusundan uzak bir hayat sürdürmekteydi. Oysa çocukları bu anlayışla yetiştirmenin hem çocuğa hem de topluma çok büyük zararları olmaktadır. Özdemir, çocukları düşünme ve sorgulamadan men etmenin doğru olmadığını, aksine bunun teşvik edilmesi gerektiğini düşünmektedir. Ona göre "Eskiden çocuklar yalnız oyun oynamakla biraz da ders bellemekle yani ezberlemekle vakit geçirirlerdi. Çocuk bir müddet sonra içine gireceği âlemin tamamen cahili kalırd. Kendini kuşatan hadiseleri merak eden ve soran çocuk terbiyesiz sayllırdl. Hâsilı bir çocuk mümkün olduğu kadar düşünmeden men edilirdi." (Özdemir, 1914b:129). Çocukta duygu, düşünce ve zeka gelişiminin evreleri ve bunların ilişkileri eskiden çok iyi bilinmediğinden çocuklar hayata yabancı olarak yetiştirilmekteydi. "ilk terbiyeye böyle başlayan bir çocuk büyüdüğ̈̈ zaman endişesiz, meraksiz, kayltsız bir şey olurdu. O vakitler bir çocuk vatan ve millet gibi kelimelerin manasını hiç bilmezdi." (Özdemir, 1914b:129). Bu şekilde yetişen çocukta vatan ve millet sevgisi de oluşmuyor, yetişkinlik döneminde de kayıtsızlık sürüp gidiyordu. Bunun bir salgın hastalık gibi bütün doğu toplumlarında bulunduğunu düşünen Özdemir; "Işste bu fena terbiyenin icabıdır ki hemen bütün şarkta yaşayan insanlarda yurt kaygisl, millet sevgisi bulunmuyordu. 'Balık suda gezer, suyu bilmez' sözündeki gibi bir vatan üstünde yaşayanlar o vatanın manasını, klymetini bilmezlerdi" demektedir (Özdemir, 1914b:129).

Vatan sevgisi ve yurt kaygısı gibi değerlerin doğu toplumlarında zayıf olmasının nedeninin milli bilinç kazandıracak kavramlara karşı duyarsızlık olduğunu söyleyen Özdemir başka bir yazıda, geçmişte çocukların ihmallerle adeta yetişmeye terk edildiğinden yakınmaktadır (Özdemir, 1914a:65). Oysa çocuğu kendi haline terk etmek değil onu gelecekteki görev ve rolüne hazırlamak gereklidir. Özdemir bu olumsuz durumun geçmişte kaldığını söylemektedir. Ona göre çocukluk kavramı anlaşıldıkça olumsuz tutumlar da değişmektedir.

Özdemir'e göre çocukluk sorumsuzluk ve görevsizlik değildir. Çocukluğu sorumsuzluk olarak nitelendiren yaklaşım çocukları gelecekten koparan, onları hayata yabancılaştıran zararlı bir düşüncedir. Oysa çocuk daha küçük yaştan itibaren içine gireceği toplum hayatına yönelik olarak 
bilgilendirilmeli, toplumsal konular ve toplum hayatı üzerinde düşünceler geliştirmesine zemin hazırlanmalıdır. Bunun sağlanacağı ortam eğitim ortamıdır. Bu noktada eğitimde amaç, çocukta öğrenme becerilerini geliştirerek onun, problemleri çözme konusunda cesaret ve kabiliyet sahibi haline getirilmesidir. (Özdemir, 1914a:65).

Ebeveyn ve mürebbilere yönelik bir yazısında Emin Naci, aynı konuyu ele alır. O, aileler ve öğretmenlerin dikkatini çocuğu geleceğe hazırlanmanın önemine çekmiştir. Uyarıları arasında ailelerin çocuklar üzerindeki aşırı himayeci yaklaşımdan kaçınmalarını öneren Naci, himayeci yaklaşımın çocuğun hayata hazırlanmasına engel oluşturduğu uyarısında bulunmaktadır. Zira himayecilikle yetișen çocuklar, hayatın gerçekleriyle yüzleştiklerinde şaşırmakta, yılgınlığa düşmekte ve başarısız olmaktadırlar. Bu başarısızlığın temelinde yetiştiricilerin bilinçsizce sürdürdüğ̈̈ himayecilik yatmaktadır (Emin Naci, 1914:28).

Dönemin çocukluk anlayışını şekillendiren bir diğer unsur sağlık konusudur. Çocuk eğitimiyle yakından ilgili görülen sağlı konusu dergilerde siklıkla vurgulanan temel konulardandır. Yetersiz ve dengesiz beslenme, özellikle büyüme çağındaki çocukların üzerinde kalıcı, derin izler bırakmaktadır. Bunların başında bedeni ve zihni gelişimin yeterliği gelmektedir. Meşrutiyet çocuğunun şartlar gereği güçlü, kuvvetli, savaşçı olması beklenmektedir. $\mathrm{Bu}$ beklentinin karşılanabilmesi, çocukların beslenme konusunu önemli kılmıștır. Çocukların daha iyi koşullarda ve daha sağlıklı bir şekilde beslenip büyütülmesi için çocuk dergilerinde ailelere yönelik açıklayıcı ve yönlendirici bilgilere sıklıkla yer verilmiştir.

Çocuğun eğitim yoluyla kazanacağı beceri ve yetkinlikleri uygulayabilmesi, kendisi ve toplumu için faydalı sonuçlar ortaya koyabilmesi için de sağlıklı olması şarttır. Sağlık konusuna bu yönüyle dikkat çeken Emin Naci "Vücudu sağlam olmayan adam ne kadar maharete, ne kadar meziyete sahip olsa yine faydasızdır. Çünkü o mahareti, o meziyeti istimal edemez, çalışamaz" diyerek çalışma hayatı için sağlıklı beslenmeye dikkat çekmektedir (Emin Naci, 1914: 28). O, çocukların, bir taraftan geleceğe hazırlık anlamında geçmiş tecrübelerden yararlanan bir eğitimden geçirilmesini önerirken diğer taraftan eğitimin, bedenen güçlü, hareketli ve dayanıklı bir bünye kazandırıcı faaliyetleri de içermesini şart koşmaktadır. Geçmiş tecrübeleri önemsemektedir, zira insanlığın geçmişte karşılaştığ 1 sorunların benzerleriyle bir şekilde karşılaşması kaçınılmazdır. Ona göre gerçek eğitimci geçmişin bu tecrübelerinden yararlanarak çocuğu geleceğe hazırlayandır (Emin Naci, 1914:30).

Çocuğu geleceğe hazırlamak ona, fiziki çevreye ve doğa koşullarına uyum sağlayabilecek donanımı kazandırmakla olur. Bunun birinci ve en önemli adımı çocukların sağlıklı şekilde yetiştirilmeleridir. "E Ĕer bir çocuk 
her yediğinden rahatsız oluyor, soğuğa-sıcă̆a dayanamıyor, atlayamıyor, zıplayamıyor, koşamıyor, güreşemiyor, ata binemiyor, yüzemiyor, silah kullanamiyor, her şeyden korkuyor, her şeyden sikalıyorsa bu çocuk nazik, kibar değil, kötürüm, ihtiyar, malül biçaredir." (Emin Naci, 1914:28). Sağlıklı zihinsel gelişim için sağlıklı bedensel gelişime ihtiyaç vardır. Bu amaçla sağlıklı ve dengeli beslenmenin yanında koruyucu sağlı önlemleri de önemli görülmüştür.

Salgın hastalıklar, yetersiz ve sağlıksız beslenme, sağlıksız yaşam alanları çocukların büyüme ve gelişmelerini olumsuz etkiler, onların normal büyüme seyrini yavaşlatır veya sağlıksız bir yaşam sürmelerine neden olacak sonuçlar doğurabilir. Özellikle savaşlarla oluşan elverişsiz ortam ve salgın hastalıkların yaygın olduğu o dönemde, koruyucu sağlı önlemlerinin, sağlıklı, güçlü bir nesil için son derece önemli olduğu açıktır. $O$ nedenle koruyucu sağlık önlemleri açısından dergilerin gerek çocuklara ve gerekse ailelere rehberlik yaptığı, bu konuda çeşitli bilgilendirici ve yönlendirici içeriklere yer verdiği görülmektedir.

\section{Çocuk ve Zeka}

Dönemin çocuk dergilerinde çocukluk anlayışını rasyonel bir temele oturtma çabası dikkat çekicidir. Çocukluk; eğitim, zeka ve öğretim gibi unsurlarla birlikte ele alınmaktadır. Öğretimde amaç tutum ve davranış değişikliği sağlamak şeklinde vurgulanır. Çocukların düzeyleri birbirinden farklıdır. Musavver Şebap dergisinde Türkçe öğretmeni olduğu belirtilen Osman imzalı yazıda bireysel farklılıklar tartışılmıştır. "Çocuklarda Zeka, Kabiliyet, Natıka" (Osman, 1910:9) başlıklı bu yazıda bireysel farklılıklara ve özürlülük durumuna dikkat çekilmiş, zeka konusunda fitri özelliklerin farklılığı, zekanın kalıtsallığı ve beceri konusu işlenmiştir. Buna göre bazen çocuk doğuştan özürlü olur ve eğitilmekle parlak bir zekaya kavuşması mümkün olmaz. Bu bir hastalıktır. Bu tür çocuklar çalışmayla bir şeyler öğrenirler, bu mümkündür ancak tam bir zeka sahibi olmaları imkansızdır. Yine bir çocuk doğuştan kabiliyetsiz olabilir. Böyle bir çocuk okuyup büyüse de işe eli yatkın olmaz. Ona göre böyle çocuklara basit bir tabirle "beceriksiz" derler. Bunun da eğitim yoluyla düzeltilmesi oldukça güçtür.

Eğitim çağının okula başlama dönemi olduğu anlayışının eskilerde kaldığı, çocuğun konuşmaya başlamasıyla eş zamanlı olarak eğitiminin başlaması gerektiği kabul edilmektedir. Pedagojik gelişmeler eğitim yaşını çok daha erken dönemlere taşısa da Meşrutiyette çocuğa yönelen ilginin onun eğitimine de erken başlanması gibi çağının pedagojik gelişmelerini iyi takip eden olumlu bir çizgide sürdürdügünü göstermektedir.

Çocuk konuşmaya başlayınca eğitimi de daha önemli görülmüştür. Çünkü çocuklar büyüklerini dinlemekte ve onlardan aldıkları şekilde konuşmaktadırlar. İşte bu aşamada çocuğu konuşmaya cesaretlendirmek 
gerekir. Yeni konuşmaya başlayan çocuğu teşvik edici, cesaretlendirici ve kullanacağı kelimeler konusunda seçici davranılması istenmektedir. $\mathrm{Bu}$ noktada eğitimcilere çok değerli öneriler sunulmuştur. Bunların başında, çocuğun kullanacağı kelimelere dikkat edilmesi, güzel söz söylemeye alıştırılması gelmektedir. Bunu başarabilmek için "Evvela edebe, marifete dair kısa cümleler ögretilmeli, boşboğazlıktan ăgzına geleni anmaktan men etmelidir" (Osman, 1910:9). Bu şekilde eğitilen bir çocuğun hem güzel ve anlamlı konuşacağı hem de çevresiyle iyi ilişkiler kuracağı belirtilmiştir. Bu noktada dil gelişimiyle düşünce gelişimi arasında paralellik kurularak, çocuğun konuşmaya başladığı andan itibaren dil gelişiminin özenle takip edilmesi istenmektedir. Çocuk aile ocağından ikinci eğitim yuvası olan okula gittiğinde dil onun en önemli kendini ifade etme aracı olacağından, okuldaki başarısı ailedeki dil gelişimi ile yakından ilgili olmaktadır. Orada kuracağı ilişkiler ve geliştireceği bilgi dağarcığı hep o dil sayesinde olacaktır.

\section{Çocuk ve Çevre}

Çocukta zeka gelișiminde kalıtsal özelliklerin yeri olduğu gibi çevresel şartların da çok önemli katkısının bulunduğuna ilişkin çocuk dergilerinde çeşitli bilgiler sunulmuştur. Eğitim işinin aynı zamanda bir çevre işi olduğuna dikkat çekilmiş, çocuğun gelişmesi bakımından çevrenin çok önemi olduğu belirtilmiştir. Örneğin "Çocuklarda Zeka, Kabiliyet, Natıka" başlıklı yazıda zeka üzerinde çevresel şartların etkisi incelenmiştir (Osman, 1910:9). Ailenin sosyo-ekonomik ve kültürel düzeyinin çocuk üzerinde doğrudan etkili olduğu tezinin işlendiği bir makalede, aile bireylerinin kendi düzeylerindeki ailelerle kuracakları ilişkinin çocuğun düşünce dil ve davranış gelişimine olumlu yansıyacağı, öğrenilenlerin de kalıcı olacağı ifade edilmiştir. Yazıda çocukların zihinler saf, hafızaları boş ve sağlam olarak nitelendirilmiştir. $\mathrm{Bu}$ boş hafiza telakkisi (tabula rasa) devrin pedagojisinde yer etmiş bir anlayıştır. Hafızanın seçici bir anlayışla doldurulması eğitimin temelini oluşturmaktadır. O nedenle çocuklar sıklıkla aile çevresindeki büyüklerle görüştürülmelidir. $\mathrm{Bu}$ görüşmelerde büyükler çocuklara hem söz ve davranışlarıyla hem de sevgi ve şefkatleriyle çok yararlı etkilerde bulunurlar (Osman, 1910:9). Ancak iyi eğitimle birlikte iyi bir aileden de söz edilmektedir. Seçkin bir aile çevresinde dünyaya gelmek, iyi bir dil eğitimi ve buna bağlı olarak nitelikli bir eğitim demektir. İyi ve kültürlü ailenin her çocuk için mümkün olmadığı belirtilerek, sorunun bu yönüyle eşitsizlikler doğurduğuna dikkat çekilmiştir. Bu eşitsizliği kısmen aşabilmek için, eğitim konusunda ailelerin tam bir titizlik ve gayret göstermeleri istenmiştir. Ailenin bu konudaki eksikliğinin okul kurumunca giderilmesi beklenmektedir.

Eğitimde çevrenin önemi "Terbiye-Tahsil-i Etfal" (İsmail Faik, 1910:6) adlı makaleler serisinde de işlenmiştir. Söz konusu yazı serisinde iklim ve coğrafi koşulların insan tabiatı ve yaşam şekilleri üzerindeki etkisine 
değinilmiştir. Mesela; sıcak bölge çocukları gevşek, soğuk bölge çocukları çevik, dağlık arazide bulunan kavim daima silah taşır, düz yerde bulunan ise silah nedir bilmeyecek kadar silaha ihtiyaç duymaz. Kara ahalisi avc1, sahil ahalisi balıkçı, kayıkçı olur. Bu durum eğitim konusunda fiziki çevrenin önemli etkisi olduğunu gösterir. Bir de aile ve toplumdan oluşan manevi çevre vardır ki bunun etkisi maddi çevreden daha çabuk görülmektedir. Çocuğun düşünce ve ruh dünyasının şekillendiği çevre olmak itibariyle manevi çevre ayrı bir öneme sahiptir. Bunun zengin-fakir, gelişmişgelişmemiş, medeni-medeni olmayan, müteşebbis ve faal olmasına göre orada yaşayan insanların, doğan çocuklar üzerine etkileri değişik olmaktadır. Yazar bu konuda Mösyö Preyer'den “Çocuğun ahlaki terbiyesi, ilmi kazanımları, içinde büyüdüğ̈̈ mahalle veyahut ahalisinin ahvaline o kadar bağlıdır ki, zeka ile ahlakın sırf tabii şekillerini gösterebilmek imkansızdır" şeklinde hayat tarzı ve çevre ile eğitim arasındaki doğrudan ilişkinin anlatıldığı bir alıntıya yer vermektedir (İsmail Faik, 1910:6).

Burada fiziki veya manevi olsun çevresel şartların zeka ve eğitim konusunda ne kadar önemli olduğuna işaret edilmektedir. Bu açıklamalar, çocuğun davranışları ve geliştirdiği tutumlar üzerinde çevrenin ne derece etkin olduğunu göstermeye yöneliktir. Çocuğun fiziksel ve soysal çevreden bu derece etkileniyor olması, ana babaya ve eğitim kurumlarına önemli yükümlülükler getirmektedir. Bunların arasında en önemlilerinden biri, çocuğa iyi bir çevre sağlamaktır. Çünkü "Bütün hayat bir tedris ve terbiyedir. Hayatın her aşamasında görülen, okunan, dokunulan şeyler insanı bir şekilde bilgilendirir ve eğitirler. Bunlar insanın fikrine, ahlakına, tabiatına bir şekil verirler ki, hangi okul bunlart verebilir?" (Ahmet Kenan, 1913:2). Çocuğa iyi bir çevre sağlama işi ana-baba olmanın gereği ve çocuğa karşı da bir görevdir. Ana baba çocuğu sağlıklı koşullarda, elverişli, sosyal ve fiziksel çevrede büyütüp yetiştirip okul ortamına hazırlamalıdır. Okul çağından itibaren çocuğa iyi bir çevre ve öğrenme ortamı sunma görevini aile ile birlikte eş zamanlı olarak okul üstlenmelidir.

\section{Çocuğun Hakları ve Görevleri}

Dergilerde çocuğun hakları ve görevleri de tartışılmıştır. Ancak çocuk haklarının yanında çocuğun görevlerine ilişkin belirlemelerin daha ağırlıklı olduğu görülmektedir. Çocuk haklarına ilişkin çaba gösteren dergiler içinde önde olan1, "Musavver Hukuk-i Etfal" dergisidir. İlk sayısındaki, "Hukuk-i Etfali Neden Çıkardım?" adlı sunuş yazısında derginin yayım amacının çocuk haklarını korumak olduğu belirtilmiştir (Şahap Rıza, 1914a:1). Söz konusu yazıda devrin çocukluk anlayışı şöyle özetlenmiştir: "Mesleğimiz tamamen çocukluğun müdafaa-i hukukudur O çocukluğun ki, bu memlekette hiçbir klymeti yoktur, biz bunu tanıtmaya, aile içinde bir mevkii yoktur, biz bunu bildirmeye, mektep âleminde bir hakk yoktur, biz bunu vermeye çalışacağız (Şahap Rıza, 1914a:1). Burada açıç̧a çocuğun ailede, okulda 
ve toplumda hak ettiği yerde bulunmadığı belirtilmekte ve buna karşı mücadelenin gerekliliği savunulmaktadır. Derginin çıkarılış amacı böyle bir mücadele üzerinde temellendirilmiş, başta aile ve okul kurumları olmak üzere çocuğun yaşantısıyla doğrudan veya dolaylı olarak ilgilenen tüm taraflara gerekli müdahalelerin yapılacağına ilişkin açık uyarılar yapılmıştır. Dergi yöneticileri temel amaçlarını, çocukları "... halin ĕglencesi, maişetin vasitası olmaktan kurtarı, maişetin kahramanı, istikbalin merdi, vatanın yardımcısı olmak üzere yetiştirmeye çalışacağız" şeklinde iddialı ve net bir şekilde ortaya koymuşlardır (Şahap Rıza, 1914a:1).

Böyle bir derginin yayın hayatına atılması son derece önemli bir gelişmedir. Söz konusu derginin çocuk haklarını korumada ne tür etkisi olduğu bilinmemektedir. Dergide, belirlenen amaçlar doğrultusunda başarılı çalışmalar yaptığına ilişkin bilgiler yer almamıştır. Her şeye rağmen çocuk haklarını savunmayı kendine görev edinin bir derginin yayımlanmış olması, çocuk konusunda oluşan duyarlılığın göstergesi olarak önemlidir. Çıkış amacı çocuk haklarını savunmak olan dergide çocuğun haklarına, görev ve sorumluluklarına ilişkin bazı önemli bilgilere de yer verilmiştir. Buna göre çocuk:

- Mektepten çıktıktan sonra doğruca evine gitmeli, yolda rastladığı kimselere selam vermeli, eve gelince büyükleri onu merak etmemesi için büyüklerine mutlaka bir kere görünmelidir.

- Akşamları ders çalışmamalıdır, çünkü akşama kadar sınıfta zihni yorulmuştur. $\mathrm{O}$ nedenle en az iki saat kadar dinlenmelidir. Bu süreyi ya arkadaşlarıyla veya aile bireyleriyle gezerek, oynayarak yahut eğlenceli bir işle meşgul olarak geçirmelidir.

- Hane içinde yemekten sonra 1 veya 1,5 saat geçmeden çalışmaya başlanmamalıdır. Çünkü yemek hazmedilmeden zihin başka bir işle yeterince meşgul olamaz.

- Kendinden büyüklere karşı hürmetli olmalıdır. Hürmetten maksat her söylenen şeyin yapılması anlaşılmamalıdır (Şahap Rıza, 1914 b:26).

Görüldüğü gibi burada çocuğun hakları yanında görevleri de sayılmaktadır. Görevlere ilişkin öne çıkan unsurlar saygı ve itaat kavramları etrafında șekillenirken, haklara ilişskin dikkate değer belirlemelere yer verilmiştir. Örneğin okuldan eve dönen çocuğun ders çalışmaması, arkadaşlarıyla oynamasına izin verilmesi onun haklarından sayılırken, yemek sonrası ders çalışmaya yönlendirilmemesinin eğitimsel gerçekler ve insan doğasına daha uygun olacağı belirtilmiştir. Meşrutiyet yıllarında bu tespitler çok önemli ve ileri görüşlü tespitler olarak değerlendirilmelidir.

Devrin diğer çocuk dergilerinde de çocuk haklarına ilişkin duyarlık görülmektedir. Ancak çocuğun haklarından ziyade görevlerinden söz 
edilmesi ağırlıklı olarak benimsenen tutum olmuştur. "Bir Çocuğun Vezaifi Neden Ibarettir?" (Abdülbaki, 1918:8) adlı yazıda sayılan görevlerden bazıları şunlardır:

- Hane dâhilinde uslu, terbiyeli oturmak, peder ve valide, birader ve hemşirelerine karşı iyi muamelede bulunmak,

- Okulda yarınki okuyacağı derslerini evde akşamdan güzelce ezberleyip, sabahleyin erkenden mektebe gitmek,

- Mektepte arkadaşlarıyla iyi, güzel geçinip onlara fena muamele etmemek,

- Kendinden büyüklerine itaat ve hürmet, kendinden küçüklerine ise şefkat ve merhamet göstermek...

$\mathrm{Bu}$ görevler, çocuğun aile ortamından başlayarak toplumun her kademesinde itaatler hiyerarşisini öğrenmesine ve onu içtenlikle benimsemesine dönüktür. Bu yaklaşım devrin çocukluk algısıyla paralellik göstermektedir. Çocuk hakları konusunda önemli bir bilinç yenilenmesi olmakla birlikte geleneksel itaat kültürünün çocuğa her firsatta kazandırılması çabasının da devam ettiği bu ifadelerde açıkça görülmektedir.

Çocuklara karşı ailelerin de bir takım görevlerinden söz edilmiştir. Bu görevler çocuğun haklarına ilişkin belirlemeler içermekten çok onun sağlıklı ve toplum için yararlı bir birey halinde yetiştirilmesine yöneliktir. "Küçük Cümleler, Tecrübeli Sözler" başlı̆̆ altında anne-babalara bu konuda şöyle bazı hatırlatmalarda bulunulmuştur ("Küçük Cümleler, Tecrübeli Sözler," 1918:3):

- Çocuklar haftada bir gün olsun yıkanmalı, saçları bir numara ile kesilmelidir. El ayak tırnaklarını haftada bir kesip ayakları her akşam yıkanmalıdır.

- Çocukları sokakta oynatmamalı, mümkün olduğu kadar bahçede ve temiz, havadar yerlerde vakit geçirtilmelidir.

- Giydirilecek kunduralar büyükçe, mintanların yakaları, pantolonlarının kemerleri bolca olmalı ki, kanın deveranına mani olmasın.

- Mide sıhhatin başlıca sermayesi olduğundan çocuklara yemek, yemiş ve benzeri gibi şeyler dikkatlice yedirilmeli, sular daima kaynatılarak içirilmelidir.

- Çocuklar daima erken kaldırılmalı, geceleri büyüklerin sohbetlerine katılıp uykusuz bırakılmamalıdır.

- Sabahtan akşama kadar sokaklarda oynayan çocuklar sokağın tabii etkisinden başka ahlaki bakımdan da etkilenirler. Ayrıca temiz olmayan 
sokaklarda her türlü mikroplardan zehirlenirler.

- Çocukların hissiyatını yükseltmek için milli, vatani, ahlaki ve fenni kitapları seçerek onları inceletmeli ve onlardan yararlandırmalıdır. Onlardan edindikleri fikirleri anlattırmalı, hatalarını da yumuşakça söylemelidir.

- Çocukları küçükten mektep, hoca, sopa ile korkutmamalıdır. Bunun acı sonuçları ve örnekleri şimdiye kadar yaşanmıştır. "Seni hocaya söyleyeyim, sana güzel bir sopa attırayım" gibi çocukları korkutacak, yıldıracak sözler mektepten, muallimden soğumasına ve onları birer umacı gibi tanımasına sebep olur. Çocuk mektebe, sinemaya gider gibi kemali hevesle gitmelidir.

Burada öne çıan uyarılar çocuğun bedensel ve zihinsel gelişimine yardım edecek bazı önlemlerin alınmasına dönüktür. Yine çocuğun psikolojik ve ahlaki açılardan gelişimini olumsuz etkileyecek unsurlar konusunda uyarılar vardır. Çocukta milli bilincin gelişmesi açısından ailelerin yakın ilgi ve duyarlık göstermesi istenmiştir. Benzer uyarı ve öneriler diğer çocuk dergilerinde de vardır. Örneğin Çocuk Duygusu'nda çocuk yetiştirmeye ilişkin bazı adap ve ahlak kurallarına ilişsin ilginç önerilere yer verilmiştir. Bunlardan "Ey valide, çocuklarını hayvanata eziyet etmekten ve hele hayvanlar öldürmekten vazgeçir. Katl ve cinayet hayvanları öldürmekle başlar" ve "Hayvanlara eziyete alışan ve bundan zevk alan çocuk büyüdüğ̈̈ zaman insanlara da acımaz ve fenalıktan zevk alır" şeklinde uyarılar ilgi çekicidir. ("Ezhar-1 Efkâr", 1913:7). Uyarıların doğa ve hayvan sevgisi aşılamaya yönelik olmaları dikkate değerdir. Hayvanlarla uğraşmaktan zevk alan çocuğa hayvan sevgisi aşılamanın gerekliliği ilginç bir gerekçeye bağlanmıştır. Buna göre hayvanlara eziyet etmeye alışan çocuk insanlara da eziyetten geri durmayacaktır. Çocuğun bu tür davranışlar sergilemesi, daha büyük kötülüklere yönelmesinin ilk adımı olabileceği ima edilmiştir. Çocuk Bahçesi'nde de benzer sözler yer almıştır:

- Bir çocuğa edilecek en büyük fenalık onu kendi keyf ve zevkine birakmadadır.

- Çocuğa nadiren müstahak olduğu vakit ceza vermek, bazen mükâfatlandırmak ve daima taltif etmek... İşte bir validenin evladına karşı yapacağı şey...

- Büyüyünce büyüklükler gösteren çocuklar ele avuca sığmayanlardır.

- Oynamayan, koşmayan, sakin çocuk ya hastadır ya da olmak üzeredir.

- Bahçesiz, güneşsiz, oyunsuz geçen çocuk hayatına pek acımalıdır.

- Oyuncaksız çocuk tembelliğin adını öğrenmeden acısını tadar.

- Çocukluğunu oyunsuz, gençliğini sporsuz geçirenler cismen olduğu kadar ruhen de sönük kalır. 
- Gençliği ataletten, çocukluktaki oyunlar saklar ve kurtarır ("Cicili Düşünmeler, Doğru Sözler,"1914:78).

$\mathrm{Bu}$ ifadelerde çocuk için oyunun önemine vurgu yapılmaktadır. Oyundan uzak duran çocuğun sağlıksız olabileceği, doğal olanın oyunu önemsemesi olduğu belirtilerek anne-babalardan çocukların oyunlarını engellememeleri istenmiştir. Oyun çocukta çalışma arzusu geliştirdiği, bu nedenle çocukların oyundan ve oyuncaktan mahrum bırakılmamaları uyarısı yapılmıştır.

Görüldüğü üzere II. Meşrutiyet şartlarında çocuk haklarına ilişkin çok önemli belirlemeler çocuk dergilerinde yer almıştır. $\mathrm{Bu}$ durum II. Meşrutiyet yıllarındaki çocukluk algısı ve çocuk hakları konusunun ne kadar önemsendiğini, günümüzle kıyaslandığında o dönemdeki yaklaşımların ne derece çağdaş olduğunu göstermektedir.

\section{İtaat Kültürü ve Saygı}

Sayg1 ve itaat konusu, dönemin çocuk dergilerinin önemsediği kavramların başında gelmektedir. Çocuk, kendini tek başına yönetecek yetkinlikte değildir. Onun ne yapacağına, neleri öğreneceğine, nelerden kaçınacağına yetişkinler karar vermektedir. Çünkü o "işlenmemiş bir elmastır" (İsmail Faik, 1910:6). Onun en verimli şekilde değerlendirilmesi için gerekli donanım büyüklerde bulunmaktadır. Bu kıymetli elmasın heba olmaması için ilk ve en önemli şart büyüklere itaattir. Kurulu nizama itaat etme, aile büyüklerine itaatle başlayan bir süreçtir. Bunun temeli ailede sağlam atılırsa, okul bu kültürü geliştirir. Hayata atıldığında birey devletine, toplumuna, amirlerine, yasalara itaat etmeyi alışkanlık halinde içselleştirmiş olur. O nedenle itaat kültürünün temelinin ailede atılması önemsenmiştir.

Dergilerde sunulan itaat kültürü dinsel bir temele dayandırılmıştır. Anne-baba kutsal olduğu için onlara itaat gereklidir. Vatan kutsaldır. Devlet, vatanın korunması için vardır ve kutsaldır. Bu kutsallık silsilesi devam edip gitmektedir. O nedenle çocuğun itaati de "kutsal olana baş eğmek" anlamında kutsal kabul edilmiştir. Orhan Mithat "Peder ve Evlat" adlı yazısında, babaları, ailenin saadeti ve toplumsal hayatın bekası için gayret gösterdiklerinden dolayı kutsamaktadır. Ona göre "Evladın o mübarek vücutlara karşı taabbüd (kulluk) ve prestij derecesinde itaat ve riayeti tabiidir" (Orhan Mithat, 1913:97). Çünkü çocuk hem maddi hem de manevi hayatını babasına borçludur. Çocuğun babasına itaati ibadet derecesinde içten ve samimi olmalı, çocuk o ruhla yetiştirilmelidir.

İtaat duygusu "Kardeş Öğ̈̈̈tleri" adlı makalede sevimli bir hale büründürülerek sunulmuştur. Çocuk itaat ederken hiçbir direnç göstermemeli, itaatinde samimi ve içten olmalıdır. Anne-baba çocuğa istikbal hazırlama uğraşında olduğu için ayrıca itaate ve saygıya layıktır. 
Onlar çocuklarını koruma adına her türlü özveriyi göstermiş, tehlikelere göğüs germişlerdir. Onların tüm çabası çocuklarının huzur ve mutluluğu içindir. Onları hoşnut etmek Tanrının hoşnutluğunu kazanmaktır (Türkoğlu, 1913:3).

İtaat konusu, çıkış amacı çocuk haklarını korumak olan "Musavver Hukuk-i Etfal" dergisinde diğerlerinden biraz farklı işlenmiştir. Büyüklere itaat ve saygının esas olduğu kabul edilmekle birlikte itaatin çocukluk görevlerine ilişkin konulardan olması gerektiği belirtilmiştir. Bu konuda devrin geçerli anlayışının dışına çıkılarak aykırı emir ve isteklere itaat edilmemesi vurgulanır: "Çünkü öyle pederler biliriz ki, bir çocuğa değil, büyük bir adama bile teklifi laylk olmayacak emirleri, ciğer parelerine etmişlerdir. Bunun için onlara vazifeniz dairesinde itaat edeceksiniz. Vazifenize mugayir emirlerini ise reddedeceksiniz." (Şahap R1za, 1914 b:26). Burada çocukların görevlerinin mutlak bir sınırlaması bulunmadığı gibi itaatsizlik durumunda büyüklerin zorlamalarına karşı onların nasıl da korunacağ1 açıklanmamıştır. Dergi yöneticileri böyle bir durumun kendilerine iletilmesi durumunda sorunun çözümünü "sizin düşünemeyeceğiniz vasitalarla onlara mani olacă̆gz" şeklinde açıklamışlardır (Şahap Rıza, 1914 b:26).

Çocuk için son derece önemli kabul edilen bu itaat duygusu çocuğa nasıl kazandırılacaktır? Bunun aile içerisinde kazandırılmasının yolu nedir? $\mathrm{Bu}$ konuda dergilerde, çocuğun oturup kalkmasından yiyip içmesine kadar bütün yaşantısının ciddi bir disiplin altında sürdürülmesi önerileri ağırlıklı bir yer tutar. Sunulan hikaye ve masallarda itaatin önemi ve itaatsizliğin zararları üzerinde çocukların düşündürülmesi de bir yöntem olarak kullanılmıştır. Örneğin; Çocuk Bahçesi'nde "Büyük Sözü Dinlenmeli" başlıklı hikayede itaatin önemi anlatılmıştır ("Büyük Sözü Dinlemeli,"1914:62). Hikayeye göre; ağacın pek sağlam olmayan dalında salıncak kuran çocuklar, dedelerinin uyarısını dikkate almazlar. Dal kırılır ve çocuklardan biri ciddi şekilde yaralanır. Kendisini uyaran dedesi günlerce onunla ilgilenmek durumunda kalır. Çocuk iyileşince itaatsizliğinden dolayı dedesinden özür diler. Buraya kadar hikayede işlenen konuda itaat etmeyen çocuk itaatsizliğinin cezasını çekmiştir. Ancak çocuk bu olaydan bir sonuç çıkarmıştır. Büyüklerin sözünü dinlemek gereklidir. Onların her sözünün bir amacı, bir hikmeti vardır. Çocuk itaatsizlikle sadece kendisi ceza çekmemiş, o sonucu önceden görüp uyarı görevini yapmış olan büyügü de sıkıntı çekmiştir. Çocuk çıkardığı bu dersi "Büyük sözü dinlemeyişimin cezasını çektim. Fakat benim kabahatimle sizi de üzmüs olmam beni daha fazla kederlendirmiştir" şeklinde itiraf eder. Dedesi de çocuğu bu seferlik affettiğini söyleyerek aynı itaatsizlik hatasına tekrar düşmemesini tembihler. Çocuk artık bir daha büyüklerinin sözünden çıkmayacaktır. Onlar yapma diyorsa bir bildikleri vardır. Hikayenin kahramanı olan çocuk arkadaşlarına, 
dolayısıyla dergi de okuyucularına, büyüklerin sözlerini sorgulamadan gereğini yerine getirmenin, önemini bu yolla anlatmıştır.

İtaat konusu şiirlerde de işlenmiş, itaatkar ve hocalarının takdirini kazanmayı amaç edinen çocuk yüceltilmiştir. Örneğin Çocuk Bahçesi’nde yer alan "yaşa evladım" (Perişan, 1914:128) başlıklı şiirde çocuk, kendisinden beklenen tavrı sergileyip büyüklerinin takdirini kazanmayı dilediği için övülmüştür. Çocuk bu itaatiyle tanrının da rızasını kazanmaktadır. Dergilerde, itaat konusunda bu anlama gelebilecek benzer bazı sözler ve özdeyişler de nakledilmiştir ("Kardeş Nasihatleri," 1913:3). Böylece içselleştirilmiş bir itaatin hem günlük yaşantıda hem dinde ne kadar önemli olduğu vurgulanmak istenmiştir.

\section{Çocuk ve Oyun}

Çocuk için oyun, barınma, beslenme gibi en doğal ve yararlı ihtiyaçlardan biridir. Bu devre hayatın en mutlu devresidir. Çocuk Duygusu'nda "Çocuk ve Oyun" başlıklı yazıda çocukluk yılları ilgiler ve yaşantı itibariyle hayatın hiçbir dönemiyle kıyas kabul etmez bir dönem olarak tanıtılmıştır. Buna göre "Sabavet (çocukluk), hayatın bir faslı klymettarıdır (önemli bölümü). Öyle bir faslı klymettar ki, bir daha ele geçmez. Ne şebabet (gençlik), ne şeyhuhet (yaşlılık), ne kadar serbest olursa olsunlar çocukluğun fevkine geçemez. Çocukluk pek başkadır. Bir ömür avaredir, yarını düşünmez. Bugün için yaşar, elem, keder, yeis kabul etmez" ("Çocuk ve Oyun," 1914:7). O nedenle hayatın hiç bir evresiyle kıyas edilemez. Bu devrede onun en önemli işi oyundur. Çünkü o oyun yoluyla kendi becerilerini geliştirmekte, eşyayı tanımaktadır. Çocuk kendince bu derece saygın ve önemli bir işle meşgul olduğu halde, onun bu ciddi işinin önemsenmemesi ve hatta engellenmesi onu üzer. Çocuğun oyundan vazgeçip küsmesi bir anlamda hayata küsmesidir. Çocuğu oyundan men etmek en hafif ifadesiyle, onun eğitiminde çok önemli bir araçtan mahrum kalmaktır. Çocuklara karşı bu olumsuz yetişkin tutumuna dikkat çeken "Çocuk Duygusu" bu konuda da şu özeleştiriyi yapmaktadır:

"Biz maatteessüf çocuk yetiştirmek sanatına vakıf değiliz. Çocuklar bir parça bağırsa, bir parça çok gülse, oynamak, sıçramak istese hemen çehre asar, onlara haşin haşin darılmaya kalkışırız. Fakat düşünmeyiniz ki, o gülmek, o oynamak, o sıçramak çocuğun hakkıdır; gıdai ruhudur. Oyunsuz o hayat bulamaz. Sonra malul olur, hasta olur. Yok, bunları düşünmez, gürültüden kurtulmak için yalnız susturmak isteriz... Bu köhne fikirlerimizi tebdil etmek lazımdır. Çocukların bu memleket, bu vatan için ne kıymettar bir unsur olduğunu teemmül ederek (düşünerek) daima onları düşünmeli, onlar için rahatımızı selp etmeli (terk etmeli) ve onlar için her fedakarlığı yapmalıyız. O gülmekler, o siçramaklar, sağlam fikirli bir millet 
yetiştirecektir. Bunu derk etmeli (anlamalı) ve esbabına tevessül etmeliyiz (gereğini yapmalıyız)" (“Çocuk ve Oyun,” 1914:7).

$\mathrm{Bu}$ eleştiriler, başta anne-baba olmak üzere çocuğun yetiştirilmesi sürecinde görev üslenen tüm eğiticilere yöneliktir. Yetişkinler burada kendi huzur ve rahatlarını temin için çocukların hayatını karartmakla suçlanmaktadırlar. Çocuk ve oyuna karşı olumsuz tutumların temel nedeni çocukluk kavramından ve çocuk psikolojisinden habersiz olmaktır.

Oyunun gereksizliğini savunanlar da olmuştur. Örneğin; "Çocuk Yurdu"nun sunuş yazısında, çocuklara faydası bulunmadığ 1 gerekçesiyle oyundan uzak durmaları, oyuna ayıracakları vakitlerini kitap ve dergi okumakla geçirmeleri önerilmiştir ("Birkaç Söz,"1913:1). Bu durum ilgili dergi yöneticilerinin, çocuk ruhundan habersiz olduğunu göstermektedir.

Oyunlardan bazılarının çocuklar için zararlı olduğunu söyleyenler de olmuştur. Örneğin Çocuk Duygusu'nda "İnsanı yorup, vücudu tahrip eden koşmacalar, kösse kapmacalar, saklambaçları terk etmeli" denilmektedir ("Zararlı Oyunlar," 1913:8). Koşmacaların, köşe kapmacaların aynı zamanda vücut sağlığı açısından faydalı olacakları düşünülmemiştir. Bu tür oyunların ne bakımdan zararlı olduğuna ilişkin açıklayıcı bilgi de verilmemiştir. Oysa bedensel gelişmenin yanında oyun çocuğun sosyalleşmesine önemli katkılar sunduğu, çocuğun ilk sosyalleşme öğretiminin oyun yoluyla başladığı kabul edilmektedir. Birlikte yaşamayı, başkalarıyla ortak çalışmayı, başkalarının hakkına saygı göstermeyi, paylaşmayı hep oyun yardımıyla öğrenir. O nedenle, geleceğin sorumluluk sahibi, çalıșkan, üretken ve vatansever vatandaşını yetiştirmede oyunun gücü ve etkisinden yaralanılmalıdır.

Çocuk için oyunun bu derece önemli olması onun eğitiminde bazı kolaylıklar sağlamaktadır. Bunun bilincinde olan dergi yöneticileri oyunu eğitim amaçlı olarak kullanmışlar, öğrenilmesi zor bir takım öğretim konularını oyunlaştırarak, zevkli bir şekilde çocuklara kavratılmasının yolunu göstermişlerdir. Örneğin, oyun yoluyla ezbercilikten kurtularak, gerçek öğrenmenin sağlanabileceğinin göstermek için bir örnek sunan Çocuk Duygusu, topaçlar yardımıyla dünyamızın ve güneş sisteminin hareket tarzının öğretildiği bir fenni oyuna yer vermiştir ("İki Topaç," 1913:5). Buna göre biri kendi etrafında, diğeri de birincinin etrafinda dönen iki topaçla oynanan bir oyunla güneş sisteminin işleyişinin öğretilmesi amaçlanmıştır. $\mathrm{Bu}$ örnekte; bir öğretim konusu, kullanılan araçlarla oyunlaştırılarak çocuğa sunulmaktadır.

Benzer bir yöntem Mekteplide görülmektedir (Dr. Cemil Necip, 1913:246). Burada yumurtanın önemi ve yapısı üzerinde durularak taze yumurta testinin nasıl yapılacağı anlatılmıştır. Bir başka örnek de Çocuk Dünyası dergisinde sunulan "Bir Damla Suyun Hikâyesi" adlı anlatımdır ("Bir Damla Suyun Hikâyesi," 1913:4). Burada da suyun buharlaşmas1, 
yağmura dönüşmesi, yağmur suyu olarak sebze ve meyvelere hayat vermesi, bunların insanlar için besin olması gibi doğal dengenin oluş ve işleyiş̧ biçimi somutlaştırılarak, adeta bir oyun şeklinde sunulmuştur. Yine bilimsel bir gerçekliğin öğretilmesinde Mektep Duyguları dergisi, ağzı dar bir şişeye bir yumurtanın nasıl sokulabileceğini oyun yoluyla öğretmiştir ("Fenni Eğlence," 1914:5). Bu konuda ilginç bir örnek de Resimli Mektep Âlemi dergisinde sunulan, Ahmet Nuri'nin "Ameli Hendeseyi Nasil Okuturum?" başlıklı yazısıdır (Ahmet Nuri, 1914:167). Burada hemen her çocuğun matematik-geometri dersinde çok korktuğundan ve bu dersi sevmediğinden söz edilmektedir. Çok korkulan bu dersin çocuklar için zevkli ve eğlenceli hale getirilmesinin mümkün olduğundan söz eden Ahmet Nuri, bu konuda kendi uygulamalarını okuyucularla paylaşmaktadır. Buna göre çizgi kavramını sıranın kenarını göstererek, açı kavramını; çocukları bahçeye çıkarıp bahçe duvarlarının birleştiği yerde köşeyi göstererek, metreyi; çocukların eline vererek ölçüm yaptırmak suretiyle ölçmeyi öğretmektedir. Bu sayede öğrenme zevkli ve kalıcı hale getirilebilir.

Çocuk dergileri oyunun önemine ilişkin belirlemelere yer verdikleri gibi çocuklar için ne tür oyunların, hangi yaş gruplarında hangi oyunların oynanmas1 gerektiği ve oyunlar için özel yerlerin bir ihtiyaç olduğu üzerinde de durmuşlardır. Konu hakkında Avrupa'dan örnekler sunan dergiler, benzerlerinin yapılması için çocukları yönlendirmek isterler. Örneğin; Çocuk Dünyası'nda yayımlanan "Şehremini Cemil Paşa Babamıza" adlı çocuklar adına yayımlanmış mektup ilgi çekicidir ("Şehremini Cemil Paşa Babamıza," 1914:1). Bu mektupta belediye başkanından Avrupa'da çocuklar için yapılan kum ve su havuzlarının benzerini yapması istenir. Mektuptan anlaşıldığı kadarıyla çocuklar Avrupa ülkelerindeki bazı uygulamalardan haberdardırlar. Kendileri de benzer imkanlara kavuşmak için belediye başkanından kendilerine yönelik benzer çalışmalar yapmasını istemektedirler. Aynı şekilde Avrupa'da özellikle Paskalya bayramının çocuklar için şenlik haline dönüştürüldüğü belirtilmiştir. Özellikle bahar mevsimine rastlayan bayramların, çocuklar için çok farklı bir ortam ve anlamda kutlandığı belirtilmiştir ("Avrupa Bayramlarında Çocuklar," 1914:161).

Ahmet Robinson imzasıyla yayımlanan "Mekteplerde Oyun" başlıklı bir yazıda ilköğretim çağındaki çocuklar için oyunun önemine dikkat çekilmiştir (Ahmet Robinson, 1913:8). Ona göre okulda oyun konusunda üç farklı yaklaşım sergilenmektedir. Birinci kısımdakiler okulda geçen zamanın değerlendirilmiş olması için vaktin dersle geçmesi gerektiğini düşünürler. Teneffüsü sadece biraz nefes alıp dinlenmek olarak zannederler. İkincisi grubu teşkil edenler biraz daha olumludurlar. Onlara göre teneffüs, biraz koşmak ve sıçramak için ayrılmış bir vakittir. 
Robinson'a göre bu iki tip yaklaşım tamamen yanlıştır. Ona göre oyun da bir ders ve terbiyedir. Bu okulda okutulan derslerin önemini inkar etmek değildir. Ancak okuldaki oyunlar da çocuk için dersler kadar etkili ve önemlidir. Derste geçen vakit nasıl önemli ise teneffüste, oyunda geçen vakit de öylece kıymetlidir. Zira okuldaki oyun, eğitimin bir parçasıdır. Çocuk oyun yoluyla fikrini, ahlakını ve bedenini geliștirme imkanı bulur. Oyunun gerçekten yararlı olabilmesi için tür ve özellikleri, çocukların yaşlarına uygunluk durumu, çocuğun hayatına ne tür bir etki bırakacağı konularının çok iyi bilinmesi gerekir. Ayrıca oyunların "merak uyandırıcı, fayda beklentisi olmadan oynanan, kuralları sade ve çok sayıda kişiyle oynanan" türden olması önemlidir.

Robinson, çocukluğun 13 yaşına kadar üç farklı devresinin olduğunu düşünür. $\mathrm{O}$ ayrıca oyunların, çocukların yaşlarına göre hayata olan etkilerinin de önemine işaret etmektedir. Çünkü bu etki doğrudan doğruya vücudun gelişmesine ve çocuğun ahlak ve düşüncesine işlemektedir. Robinson oyun çağlarını çocukların yaşlarına göre üç devreye ayırdığı gibi, oyunları da oynanıș biçimlerine göre üçe ayırmaktadır. Bunlar şahsi oyunlar, şahsi yarışmalar ve müşterek yarışmalardır. Birinciden bireysel düşünme, icat etme fikri geliştirir. İkinci tür oyunlar çocuğa kendini koruma ve mücadele azmi kazandırır. Bunlar kavgacılık, geçimsizlik duygusuna da yöneltebilir. Üçüncüsü ise ortak savunma ve korunma hukuk ahlakını kazandırır ki bundan vatan, millet, hükümet idaresi fikri çıkar. Bu oyunları oynattıracak olanlar -ki bu öğretmenlere bir uyarıdır- öncelikli olarak oyunun bu faydayı sağlayıp sağlamayacağını iyi düşünmelidirler. Ona göre "Talim ve terbiye ile uğraşan ve hakiki bir Osmanl unsuru yetiştirmeye çalı̧̧an zevat; oyunu, oyundan çok bir iş, bir ahlak ve fikir ve beden eğitimi ve ders olarak görmeli, usulü dairesinde birçok oyunları çocuklara ögreterek onları temiz düşünceli, sağlam ruh ve vücutlu adamlar olarak yetiştirmelidir"'(Ahmet Robinson, 1913:8).

Çocuk oyun ortamında uyum alışkanlığını kazanarak gelecekteki sosyal yaşantısına da hazırlık yapmakta, bu yolla çocuğa girişimcilik ruhu kazandırmaktadır ki, devrin ihtiyaç duyulan insanının özelliklerinden birisi de girişimciliktir. Bu ruhun geliştirilmesi adına dergilerde çeşitli içerikler yer almıştır. "Bakkalcılık Oyunu" bu konuda güzel bir örnektir ("Bakkalcılık Oyunu," 1914:1). Oyun, Kaya ve Türkan adlı iki çocuğun kendi aralarında pirinç vb şeylerin alım satımını konu almaktadır. Bu oyunun bir yönü alışveriş yöntemini öğretmesi, diğer ve önemli bir yönü de cinsiyet ayrımı yapmadan çocuğu küçük yaşta ticarete alıştırmasıdır. Bazı fen konularının oyun tarzında deneylerle verilmesi hem çocuğun ilgisini çekmekte hem de öğrenilenlerin kalıcılığını sağlamaktadır. Fenni eğlenceler ve benzeri başlıklar altında bu tür oyunlaştırılmış fen konuları dergilerde sıklıkla yer almıştır. Bu konuda Mektepli dergisi örnek olarak verilebilir. "Fenni 
Eğlenceler ve Oyunlar" başlığı altında tatlı su kavanozuna konan yumurtanın batması ve tuzlu sudaki yumurtanın yüzmesi gibi basit bir örnekten hareketle suyun kaldırma gücü ile yoğunluğu arasındaki ilişki oyun tarzında ve resimler eşliğinde sunulmuştur ("Fenni Eğlenceler ve Oyunlar," 1913:132). Benzer uygulamalara diğer çocuk dergilerinde rastlanmaktadır. $\mathrm{Bu}$ tür içerikler, oyun ile öğrenme arasındaki ilişkinin çok iyi değerlendirilmesine dönük öğretici, çocukların eğitimiyle görevli tüm eğiticileri uyarıcı ve yönlendirici işlev görmektedirler.

Dergilerde çocuk oyunları konusunda cinsiyet ayrımı belirgin olmasa da yapılmıştır. $\mathrm{Bu}$ ayrım, çocukların kendi cinsel kimliklerini tanımalarına yardımcı olması açısından önemli görülmüştür. Cinsler arasındaki fizyolojik farklılıklara bağlı olarak üslenmeleri gereken bireysel ve toplumsal rollerde bir takım farklılıkların bulunacağı kabul edilmektedir. Bu rolleri büyük ölçüde geleneklerle belirlemekte, çocuklardan, cinsiyete göre belirlenen bu rollerin benimsenmesi ve gelecek için bu rollere hazırlanması beklenmektedir. Dergilerde oyun konusundaki içeriklerde cinsiyete göre bir ayrım yapılmamış olsa da daha ziyade erkek çocukların düşünüldüğü izlenimi alınmaktadır.

Oyuncaklar konusu dergilerde pek işlenmemiş konulardandır. Bazı dergilerde oyuncak yapımından söz edilse de bunlar önemli bir yekûn tutacak düzeyde değildir. Konuya Çocuk Dünyası'ndaki "Yumurtadan Kuş" örnek olarak gösterilebilir ("Yumurtadan Kuş," 1913:5). Yine Talebe Defteri'nde resimler eşliğinde oyuncak tayyare ("Oyuncak Tayyare," 1913:392) ve sinema makinesinin nasıl yapılacağ1 ayrıntılı anlatılmıştır ("Sinema Makinesi," 1913:429). Ayrıca "Milli Oyuncaklarımız" başlı̆̆ altında birçok oyuncak adından söz edilmiştir ("Milli Oyuncaklarımız," 1913:110). Bunlardan bazıları: Ok, aşık kemiği, uçurtma, balmumu ördek, cirit, çelik-çomak, çember, türlüce ${ }^{*}$, davul, def, zurna, sapan, topaç, tabanca, kargı, kaval, kement, gürz, tıptıp, kalkan, kılıç, kırbaç, kızak, mızrak şeklinde sıralanabilir. Ayrıca "Eyüp oyuncakları" başlığı altında: beşik, kursaklı düdük, hacıyatmaz, kocakarı dırıltısı, aynalı testi, çocuk arabası gibi oyuncakların varlığından söz edilmiştir.

\section{Çocuk Oyunlart}

Dergilerde pek çok çocuk oyununa yer verilmiştir. Kazandırılmak istenen davranış ve alışkanlıklar için oyundan yararlanmak temel düşüncedir. Bunu gerçekleştirmede hedef kitleye, seviyesine göre değişik oyunlar sunulmuştur. Örneğin Çocuk Dostu okul öncesine yönelik bir görünüm arz ettiğinden bu seviyedeki çocuklara yönelik oyun tanıtımı yapmıştır. "Açıl Kilit" oyunu, tekerlemesi olan ve çocuklar için neşeli bir oyundur ("Açıl

\footnotetext{
* Ağaç kabuğundan yapılan bir çeşit düdük.
} 
Kilit," 1914:5). Aynı dergide kukla oyununu tanıtan küçük bir hikayeye de yer verilmiştir ("Kukla Oyunu," 1914:5).

Mektepli'de çeşitli başliklar altında sunulan "Fenni Eğlenceler"den hikmeti tabiiye denilen, tabiat kurallarına dayalı eğlenceler, sade, kolay ve denenebilirdir. Aletsiz şekil çizimi ise pratik uygulamalarla ortaya konan şekiller, ipler, bükülmüş kâğıtlarla yapılan eğlendirici oyunlar, araç kullanmadan çeşitli şekiller çizmek şeklindedir. Oyunların bir kısmı dinlendirme, eğlendirme, siyasal bilinç ve vatanseverlik erdemi kazandırmayı hedefleyen türdendir. Birinciye örnek; içi boşaltılmış ve ince bir delikten, yarıya kadar ince kumla doldurulmuş yumurtanın değişik konumlarda dengelenmesine yönelik bilgi kazandırıcı bir uğraştır. İkinciye örnek ise, ders aracı üretimi becerisi kazandırmayı da amaçlayan, çakı bıçağından pergel, bükülmüş bir kağıttan cetvel, iki zit yönde bükülmüş bir kağıttan gönye olarak yararlanmanın öğretilmesidir ("Fenni Eğlenceler," 1913:13-15). Siyasal bilinç kazandırıcı oyunlara ise Türk'ün gücünü simgeleyen çeşitli oyunlar gösterilebilir.

Dergilerde pek çok çocuk oyunu açıklamalarla anlatılmıştır. $\mathrm{Bu}$ oyunların daha ziyade dönemin siyasal şartlarından etkilendikleri görülmektedir. Siyasal bilinç kazandırma amacıyla işlenen intikam duyguları da bu oyunlara önemli ölçüde yansımıştır. Dönemin çocuk dergilerinde siyasal, öğretici ve eğlendirici olmak üzere üç ana başlık altında toparlanabilecek türden oyunlar yer almıștır. Bunlardan siyasal ve askeri içerikli olanlar, Köse Kâhya, Düşman Askerleri, İntikam Oyunu, Türk Oyunu, Bulgar Kaçtı oyunları sıralanabilir. Öğretici ve dinlendirici oyunlara örnek olarak Hikaye Oyunu, Pusula Oyunu, Hece Tamamlama, Renk Oyunu, Kelime Oyunu, Kafiyecilik Oyunu, Yüzük Kaçırma, Numara Bilmek sayılabilir. Eğlendirici ve spor amaçlı oyunlara da Ebem Beni Tutamaz, T1k Tık Oyunu, Çuval Koşusu, Kale Kaçkını gibi oyunlar gösterilebilir. Bu oyunların oynanıs șekilleri başta Çocuk Duygusu ve Cocuk Dünyası olmak üzere çeşitli çocuk dergilerinde anlatılmıştır. Talebe Defteri'nin altıncı sayısında da çocuklardan oyun isimleri istenmiş ve yedinci sayıda okuyucudan gelen oyun isimleri tek tek sıralanmıştır. Bu sayıda yüzü aşkın çocuk oyunun adına yer verilmiştir ("Çocuk Oyunları," 1913:110).

\section{Sonuç ve Değerlendirme}

II. Meşrutiyet dönemi çocuk dergilerde, bir "çocukluk felsefesi” ortaya koyacak kuramsal yaklaşımlara pek rastlanmaz. Bu tutum, dönemin tüm çocuk dergilerinde görülür. Çocuğa yaklaşımda, "çocukluk" fikrinden ziyade "geleceğin yetişkini” düşüncesi, dergilerin ortak özelliklerinden biridir. Genellikle çocukluk, kendi doğasıyla yer almaz bu dergilerde, yetişkin hayatının bir hazırlık devresi olarak ele alınır ve bu anlamda iyi değerlendirilmesi gerektiği vurgulanır. Bu anlayışın sonucu olarak çocukluk, 
yetişkinlikten bağımsız olarak ele alınmamış, sorun çözen, toplumuna faydalı olan, bilgili ve aydın yetişkin modeline göre değerlendirilmiştir. $\mathrm{Bu}$ itibarla, çocuklara "potansiyel yetişkin" olarak bakıldığı söylenebilir.

Eğitimden sağllğa, el becerisinden çocuk oyunlarına kadar, çocuklar için öngörülen bütün faaliyetler, çocuğa görelik ve uygunluk yönünden değil, gelecekte toplum için sunabileceği katkılar açısından değerlendirilmiştir. Öyle ki, çocuk oyunlarında bile bu kaygı gözetilmiştir. Oyunlar çocuğun doğal bir ihtiyacı değil de, gelecekteki hayat için hazırlanma, bir prova, bir talim olarak düşünülmüştür. Bu bağlamda, en azından vatan ve millet sevgisini aşılayıcı nitelikte olmaları gerektiği düşünülmüştür.

Günümüz eğitim anlayışında oyun önemli bir eğitimsel faaliyet olarak görülse de uygulamada çocuklar bu faaliyetten önemli ölçüde mahrum kalmaktadırlar. Hedeflenen gelecek uğruna şartların ve ailelerin zorlamasıyla çocukluk yılları okul ile dershane arasında geçmektedir. Bu durum bilgi yüklemeyi oyundan daha önemli gören bir anlayışın devamıdır. $\mathrm{Bu}$ yaklaşımın çocuklar üzerindeki etkisi derinlemesine araştırılmaya değer bir konudur.

Çocuğun doğasına ilişskin tartışmalar, onun bir "boş levha" (tabula rasa) olarak algılandığını göstermektedir. Toplumun aydınlanmasında, eğitime verilen bu değerin, kısmen batı kaynaklı olduğu söylenebilir. Zira çağdaş batı'da çocuk eğitimine ilişkin bazı akımların ortaya çıktığı, bunların Osmanlı aydın ve eğitimcilerini, etkilediği bilinmektedir. Tabiata göre adam yetiştirme olarak özetlenebilecek eğitim anlayışlarının toplumsal, ihtiyaçlar ve sorunlara dikkat çekilerek bu ihtiyaçları giderecek donanımdaki insanı yetiştirmeye yöneldiği görülmektedir. Burada "çocuğa görelik" ilkesinden çok, "topluma görelik" ilkesinin benimsendiği belirgindir.

Çocuk dergilerinin, çocuğa potansiyel yetişkin gözüyle bakması, II. Meşrutiyet döneminin özel şartlarıyla ilgilidir. Zira dergilerin içeriği, dönemin sosyal ve siyasal sorunlarıyla yakından ilgilidir. Bu durum, çocukların yakın gelecekte birer yetişkin olarak yüklenecekleri toplumsal görevlere hazırlanmalarının önemli görüldügünü göstermektedir. Unutulmamalıdır ki, II. Meşrutiyet yılları Türk milleti için büyük felaketlerin yaşandığ dönem olmuştur. Balkan savaşlarında ülke topraklarının önemli bir kısmı elden çıkmış göçler, salgın hastalıklar, kıtlık gibi felaketler toplumu derinden sarsmıştır. $\mathrm{Bu}$ durumda çocuk dergilerinin sosyal ve siyasal konulara ağırlık vermesi doğal karşılanmalıdır. Zira yetiştirilecek nesli, savaşlarda kaybedilen vatan topraklarını geri almak, kırılan milli onuru tamir etmek, yaşanan ekonomik ve sosyal sıkıntıları sona erdirmek gibi çok çetin görevler beklemektedir. 


\section{KAYNAKLAR}

Abdülbaki. (19 Eylül 1918). Bir Çocuğun Vezaifi Neden İbarettir, Musavver Mektep, (4), 8.

Açıl Kilit. (14 Mayıs 1914). Çocuk Dostu Dergisi, (4), 5.

Ahmet Hamdi. (23 Temmuz 1913). Bir Hasbihal, Çocuk Duygusu, (6), 2.

Ahmet Kenan. (23 Temmuz 1913). Mektep, Resimli Mektep Âlemi, (1), 2.

Ahmet Nuri. (28 Ocak 1914). Ameli Hendeseyi Nas1l Okuturum, Resimli Mektep Âlemi, (11), 167

Ahmet Robinson. (23 Temmuz 1913). Mekteplerde Oyun, Resimli Mektep Alemi, (1), 8.

Akyüz, Yahya. (2006) Türk Eğitim Tarihi, (11. Basım). Ankara: Pegem A Yayıncilik.

Akyüz, Y. (1978). Türkiye'de Öğretmenlerin Toplumsal Değişmedeki Etkileri, Ankara: Doğan Basımevi.

Akyüz, Y. (2001). Tanzimat'tan Cumhuriyet'e Okul Yöneticiliğinde Dönüşümler ve Kadın Okul Yöneticiliği, Tarih ve Toplum, Cilt: 35, (207), 58.

Avrupa Bayramlarında Çocuklar.(21 Mayıs 1914). Çocuk Dünyası,(61), 161.

Bakkalcılık Oyunu. (21 Mayıs 1914). Çocuk Dostu, (5), 1.

Bir Damla Suyun Hikâyesi. (3 Nisan 1913). Çocuk Dünyasl, (2), 4.

Birkaç Söz.(22 Mayıs 1913). Çocuk Yurdu, (1),1.

Büyük Sözü Dinlemeli. (26 Mart 1914). Çocuk Bahçesi, (4), 62.

Cemil Necip. (9 Ekim 1913). Yumurta, Mektepli, (15), 246

Cicili Düşünmeler Doğru Sözler.(2 Nisan 1914). Çocuk Bahçesi, (5), 78

Çocuk Dünyasının Düşüncesi. (27 Mart 1913). Çocuk Dünyası, (1), 1

Çocuk Oyunları. (28 Ağustos 1913). Talebe Defteri, (7), 110

Çocuk ve Oyun. (21 Mayıs 1914). Çocuk Duygusu, (49), 7.

Emin Naci. (26 Şubat 1914). Terbiye-i Etfalde İkinci Noktayı Nazar, Musavver Hukuki Etfal, (4), 28.

Ezhar-1 Efkâr. (6 Kasım 1913). Çocuk Duygusu, (21), 7.

Fenni Eğlence. (23 Şubat 1914). Mektep Duyguları, (10), 5 
Fenni Eğlenceler. (28 Mayıs 1913). Mektepli, (1),13-15

Fenni Eğlenceler ve Oyunlar. (23 Temmuz 1913). Mektepli, (8),132.

Hayatı Öğrenelim. (18 Şubat 1910). Arkadaş, (3), 71.

İki Topaç. (19 Haziran 1913). Çocuk Duygusu, (1), 5

İsmail Faik. ( 14 Nisan 1910). Terbiye-Tahsil-i Etfal, Musavver Şebab, (13), 5.

Kardeş Nasihatleri. (19 Haziran 1913). Çocuk Duygusu, (1), 3.

Kukla Oyunu. (28 Mayıs 1914). Çocuk Dostu, (7), 5.

Küçük Cümleler, Tecrübeli Sözler. (26 Eylül 1918). Musavver Mektep, (5), 3.

Küçük Turgut'un El işleri. (7 Mayıs 1914). Çocuk Dostu, (3), 2.

M.F.Ş. (7 Ağustos 1913). Yaşamak Üzerine, Çocuk Duygusu, (8), 2.

Nezihi Behzat. (4 Şubat 1910). İhtiyaç-1 Maarif, Musavver Şebab, (3), 2.

Orhan Mithat. (28 Ekim 1913). Peder ve Evlat, Resimli Mektep Âlemi, (7), 97.

Osman. (3 Mart 1910). Çocuklarda Zekâ Kabiliyet Natıka, Musavver Şebab, ( 7), 9 .

Özdemir.( 2 Nisan 1914 a). Sultan Orhan Oniki Yaşındayken, Çocuk Bahçesi, (5), 65.

Özdemir. (30 Nisan 1914 b). Hamdolsun Çocuklarımız Düşünüyor, Çocuk Bahçesi, (9), 129.

Perişan. (23 Nisan 1914). Yaşa Evladım, Çocuk Bahçesi,(8), 128.

Rıza Tevfik. (12 Şubat 1914). Çocuk Dünyası, (47), 3.

Şahap Rıza. (5 Şubat 1914 a). Hukuk-i Etfali Neden Çıkardım, Musavver Hukuk-i Etfal, (1), 1 .

Şahap Rıza. (26 Şubat 1914 b). Vazife, Musavver Hukuk-i Etfal, (4), 26.

Şehremini Cemil Paşa Babamıza. (8 Ocak 1914). Çocuk Dünyası, (42), 1

Şimdiki Çocuklar. (9 Nisan 1914). Çocuk Bahçesi, (6), 91.

Türkoğlu. (12 Haziran 1913). Kardeş Öğütleri, Çocuk Yurdu, (4), 3.

Yumurtadan Kuş. (18 Eylül 1913). Çocuk Dünyası, (26), 5

Zararlı Oyunlar (26 Haziran 1913). Çocuk Duygusu, (2), 8. 